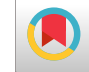

\title{
Potential Drugs for Treating COVID-19 Infection
}

\author{
Mehrdad Mohammadi (i] ${ }^{1,}{ }^{*}$, Tim Sandle $\left(\mathbb{D}^{2}{ }^{2}\right.$, Sajad Rajabi ${ }^{3}$, Ahmad Khorshidi $^{1}$ and Ahmad \\ Piroozmand ${ }^{4}$ \\ ${ }^{1}$ Department of Microbiology and Immunology, Faculty of Medicine, Kashan University of Medical Sciences, Kashan, Iran \\ ${ }^{2}$ Bio Products Laboratory, Elstree, Hertfordshire, United Kingdom \\ ${ }^{3}$ Department of Gynecology and Obstetrics, School of Medicine, Iran University of Medical Sciences, Tehran, Iran \\ ${ }^{4}$ Department of Microbiology and Immunology, School of Medicine, Kashan University of Medical Sciences, Kashan, Iran \\ "Corresponding author: Ph.D. Student of Medical Bacteriology, Department of Microbiology and Immunology, Faculty of Medicine, Kashan University of Medical Sciences, \\ Kashan, Iran. Email: mehrdad.mohammadi1984@gmail.com
}

Received 2020 July 01; Revised 2020 August 24; Accepted 2020 September 24.

\begin{abstract}
The novel Coronavirus Disease 2019 (COVID-19) appeared as an emerging respiratory disease in December 2019 in Wuhan, Hubei province, China, and then spread rapidly worldwide, being declared a pandemic on March 11, 2020. Researchers are attempting to discover specifically designed antiviral treatments for COVID-19. Several therapeutic agents such as Interferon$\alpha$, Lopinavir/Ritonavir, Ribavirin, Chloroquine, Chloroquine phosphate, Hydroxychloroquine, Arbidol, Favipiravir, Remdesivir, Darunavir, Imatinib, Teicoplanin, Azithromycin, COVID-19 convalescent plasma, other potential antiviral drugs, and Chinese herbal agents are now being clinically studied to examine both pharmaceutical efficacy and safety for COVID-19 treatment in several countries. Some favorable results from these studies have been obtained to date. This review article summarizes and reiterates drugs that are potentially efficient against COVID-19.
\end{abstract}

Keywords: Novel Coronavirus, COVID-19, Antiviral Drug, Treatment

\section{Context}

The first patient infected with the novel coronavirus emerged on December 30, 2019, in a sea-food restaurant in Wuhan, Hubei province, P.R. China. Then, the infection spread to most countries of the world, up to 200 countries (1-3). The World Health Organization (WHO) named the pathogen, initially called 2019-nCoV, as SARS-CoV-2 on February 12. The virus causes Coronavirus Disease 2019 (COVID-2019). The WHO report declared the virus as responsible for a pandemic on March 11, 2020 (4, 5). The initial whole-genome sequence of 2019-nCoV (COVID-19) was available at GenBank (Wuhan-Hu-1, GenBank accession number MN908947) of the NCBI on January 10, 2020 (2, $6)$. In the phylogenetic analysis, COVID-19 belongs to the realm of Riboviria, the phylum of incertae sedis, the order of Nidovirales s. the family of Coronaviridae, the subfamily of Orthocoronavirinae, and the genera of betacoronavirus (710). It shares ancestry with bat coronavirus HKU9-1, and is similar to Severe Acute Respiratory Syndrome (SARS) coronaviruses (8). In terms of infectivity, the genomic analysis reveals how the spike protein of SARS-CoV-2 reacts with the human angiotensin-converting enzyme 2 (ACE2) receptor (11-14). ACE2 is found in cardiomyocytes, cardiac fibrob- lasts, and coronary endothelial cells. Importantly, ACE2 serves as a regulator for heart function (Figure 1) $(11,12,15$, 16).

The Corona Viruses (CoVs) contain non-segmented, single-stranded, positive-sense RNA (+ssRNA; 30 kb) genomes (9). SARS-CoV-2 has the largest RNA genome within the family, containing approximately 30 kilobases (kb) genome $(9,17)$. The genomic pattern and organization of SARS-CoV-2 are similar to those of other betacoronaviruses $(7,8)$. Despite being classified as a betacoronavirus, SARS-CoV-2 differs from SARS-CoV and MERSCoV (7). SARS-CoV-2 gene nucleotide similarity to MERSCoV and SARS-CoV is less than $80 \%$ and $89.10 \%$, respectively $(2,7,10)$. A minimum of six Open Reading Frames (ORFs) are present in the genome (7). Several proteins are formed from these ORF products via cleavage through the proteolysis process. PLpro and 3CLpro carry out these proteolysis reactions (18). 3CLpro plays a principal role in the replication of virus particles $(7,18)$. Therefore, 3CLpro presents the best potential target for anti-coronavirus inhibitors and should be investigated further for drug design (18). Other ORFs adjacent to the 3' end can encode no less than four major structural proteins: spike (S), membrane (M), envelope (E), and nucleocapsid (N) proteins (7). 


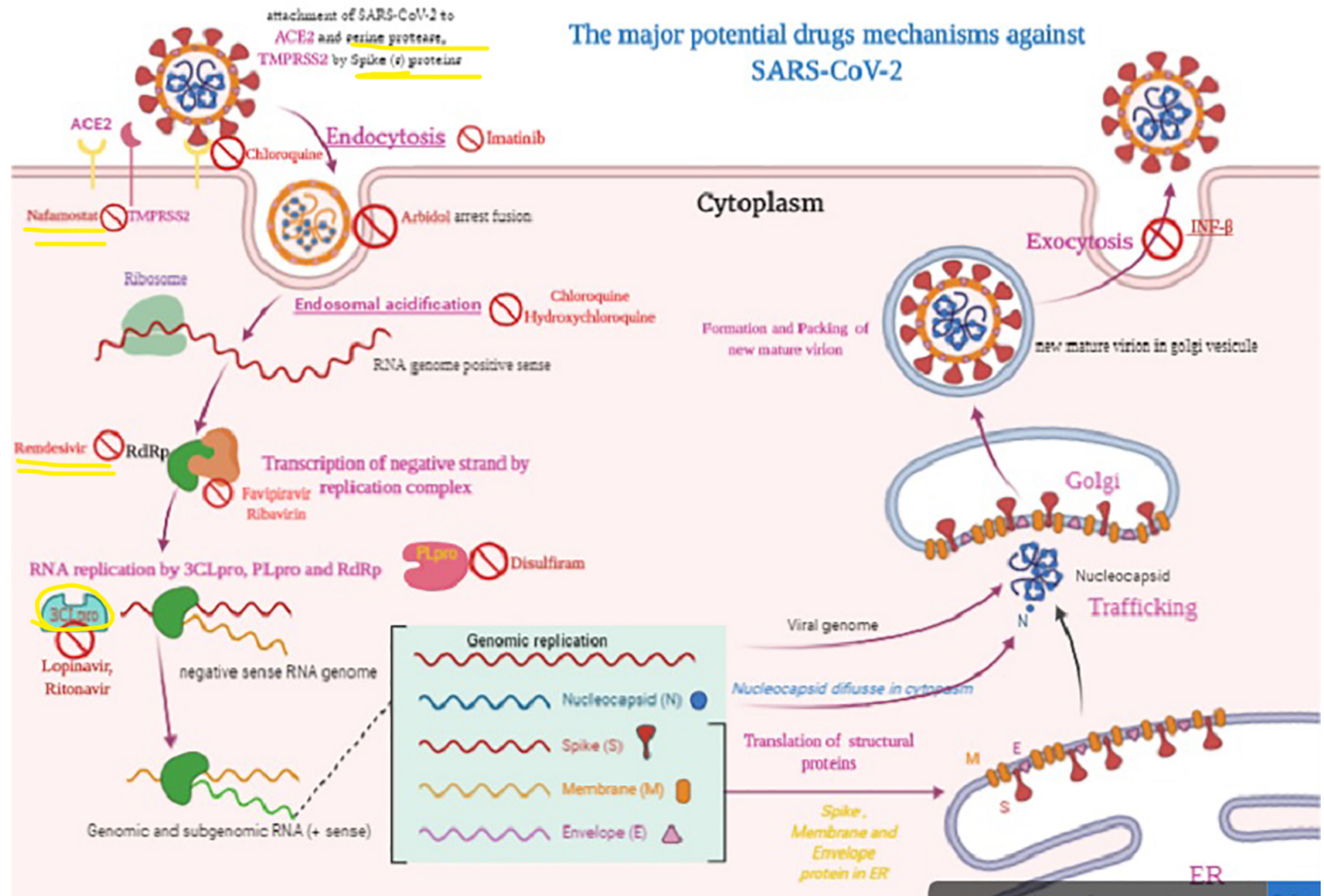

Created in BioRender.com bio

Figure 1. The major potential drugs mechanisms against SARS-CoV-2, This graphical abstract demonstrates the life cycle of SARS-CoV-2 in the host cells. The target of potential drugs exhibited by red banned icon in virus life cycle

Scientists are endeavoring to find drugs to treat COVID19. These attempts are currently focused on at least 30 drugs such as natural agents, Western drugs, and traditional Chinese therapeutic agents, each of which is potentially efficient against COVID-19. Clinical studies have been rapidly conducted on some of these agents, and the results are indicative of their initial efficacy against COVID-19 (1922). The current study aimed to review the possible and proposed drugs for the treatment of COVID-19. A summary of information about these drugs is provided in Table 1. It is clear that extensive clinical research is needed to conclusively confirm the effect of these drugs on COVID-19. The drugs studied in the present survey may also have side effects; thus, in prescribing these drugs, it is necessary to evaluate the cost-benefit ratio. Some side effects of these drugs aggravate the symptoms of coronavirus. In these cases, more care is needed in prescribing the drug. Some other side effects of the drug may be negligible in the face of virus-related mortality.

\section{Method}

All articles in PubMed containing keywords COVID-19, virus, and drug were collected using the search builder software. Then, filtering was performed based on the presence of keywords in the title and abstract of the articles. Finally, from the articles in the created library, the related information was extracted and compared, and conclusions were made.

\subsection{Antiviral Treatment}

The antiviral treatment options under examination include Interferon $\alpha$ (IFN- $\alpha$ ), Lopinavir/ritonavir, Chloroquine, Chloroquine phosphate, Hydroxychloroquine, Ribavirin, Arbidol, Favipiravir, Remdesivir, Darunavir, Imatinib, etc. Some of these medicines have been suggested for use in the most recent version of the Guidelines for the Treatment of COVID-19 by the WHO $(23,24)$. Each of these candidate products is considered in detail as follows. 


\subsection{Interferon- $\alpha$}

Interferon- $\alpha$ (IFN- $\alpha$ ) is a broad-spectrum antiviral immune protein (19). It is frequently applied for hepatitis treatment; however, it can reportedly suppress the in vitro reproduction of SARS-CoV (25). Viral load can be diminished by interferon- $\alpha$ at the early stages of infection, which subsequently proceeds to relieve clinical manifestations and truncate the period of infection $(19,26)$. The major administration method is vapor inhalation, and the recommended usage is as follows:

1. Nebulization: $200,000-400,000 \mathrm{IU} / \mathrm{kg}$ or $2-4 \mu \mathrm{g} / \mathrm{kg}$ interferon- $\alpha$ in $2 \mathrm{~mL}$ sterile water is used; nebulization is carried out twice a day for a course of 5-7 days $(27,28)$;

2. Spray: This method is used for high-risk patients with close contact with patients who are suspected of being infected with COVID-19 or during the primary stages of manifestations in the upper respiratory tract. The guideline is to administer 1-2 sprays for each of the two nasal cavities and 8-10 sprays on the oropharynx. A dose of 8000 IU should be used in each injection, and each injection is carried out once every 1-2 hours; a total of 8-10 sprays per day are applied for 5-7 days $(27,28)$.

\subsection{Lopinavir/Ritonavir}

Lopinavir/Ritonavir has been used in adult patients infected with COVID-19 pneumonia (29). The efficacy and side effects have not been determined. Lopinavir/Ritonavir is a drug used to treat human immunodeficiency virus (HIV) infection in children over 14 days of age when used in combination with other protocols (30-32). The efficiency dosage of Lopinavir/Ritonavir is $200 \mathrm{mg} / 50 \mathrm{mg} /$ capsule, two capsules each time, two times/day with oral administration $(21,27,29,33,34)$ (Table 2$)$.

\subsection{Ribavirin}

Ribavirin is a broad-spectrum antiviral drug act by the mechanism of nucleoside analog $(30,35)$. Ribavirin is administrated via intravenous infusion $(36,37)$. For adults, the efficiency dose of Ribavirin is $500 \mathrm{mg}$, 2-3 times per day when used along with IFN- $\alpha$ or Lopinavir/ritonavir $(37,38)$.

\subsection{Chloroquine, Chloroquine Phosphate, and Hydroxychloro- quine}

Chloroquine is a broad-spectrum antiviral drug, but it is most commonly used as an antimalarial drug (39). Chloroquine was discovered to obstruct COVID-19 infection by inhibiting viral enzymes such as DNA and RNA polymerase or viral processes, including assembly, protein glycosylation, transport of newly synthesized virus particles, and virus release at a low-micromolar concentration $(24,40)$. The half-maximal effective concentration (EC50) and half-cytotoxic concentration (CC50) of Chloroquine were found to be $1.13 \mu \mathrm{M}$ and greater than $100 \mathrm{mM}$, respectively $(24,41)$. The phosphate salt portion of chloroquine is called chloroquine phosphate. Indeed chloroquine, which as a quinolone interferes with the biosynthesis of nucleic acids, is, in fact, used for the treatment of malarial infections or inflammation $(42,43)$. It is administered orally with an efficacy dose of $500 \mathrm{mg}$ (300 $\mathrm{mg}$ for chloroquine), twice a day for adults $(42,43)$. Hydroxychloroquine has in vitro activity against COVID-19 by inhibiting viral enzymes such as DNA and RNA polymerase or viral processes, including assembly, protein glycosylation, and transport of newly synthesized virus particles (21, 41, 43-45). Hydroxychloroquine is administered as oral tablets. Its efficacy dose is $400 \mathrm{mg}$ two times on the first day, followed by 200 $\mathrm{mg}$ two times a day for four days $(21,41,43-45)$ (Table 2 ).

\subsection{Arbidol}

Arbidol is a Russian-made antiviral drug for influenza infection, generally used in Russia and China (46). Arbidol inhibits membrane fusion (46). Arbidol impedes the interaction between the virus and its target host cells through inhibiting the viral capsid-target cell membrane fusion, thereby hindering the entry of the virus into the target cell (46). Arbidol has an in vitro anti-COVID-19 effect at a concentration of 10-30 $\mu \mathrm{M}(47)$.

It is administered orally, and its efficacy dose for adults is $200 \mathrm{mg}$ three times a day. The maximum period of treatment is 10 days (47).

\subsection{Favipiravir}

Favipiravir specifically inhibits the activity of RNAdependent RNA polymerase (RdRP) in the influenza virus and has a demonstrable effect against various viruses like yellow fever virus, Zika virus, foot-and-mouth disease virus, and West Nile virus; it is, therefore, a candidate for producing broad-spectrum effects against SARS-CoV-2 $(48,49)$. Favipiravir is currently undergoing clinical trials and in vitro analysis in treating COVID-19 (21, 47). Favipiravir is considered a prodrug that becomes active following metabolization and conversion into the phosphoribosylated form (favipiravir-RTP) in cells. This drug inhibits the activity of viral RNA polymerase when recognized by this enzyme as substrate $(21,47,49)$. It is administered orally, and its efficacy dose is $500 \mathrm{mg}$ on the initial day of treatment followed by two doses of $600 \mathrm{mg}$ for 13 days, in combination with aerosol inhalation of interferon-alpha (five million units two times a day) $(21,47)$. 


\begin{tabular}{|c|c|c|c|c|c|}
\hline & Classification & Reasoning for Utilize & Mechanism of Action & Proof/Try & Probable Side Effects \\
\hline Chloroquine & Antimalarial & $\begin{array}{l}\text { In vitro activity with } \\
\text { immunomodulating } \\
\text { actions }\end{array}$ & $\begin{array}{l}\text { stopping viral enzymes } \\
\text { and inhibiting processes } \\
\text { of viral DNA and RNA } \\
\text { polymerase, viral } \\
\text { protein glycosylation, } \\
\text { virus assembly, new } \\
\text { virus particle transport, } \\
\text { and virus release, } \\
\text { Inhibition of cell } \\
\text { receptor ACE2 }\end{array}$ & $\begin{array}{l}\text { Pre-clinical analysis for } \\
\text { the process of definitive } \\
\text { decision against } \\
\text { COVID-19. There have } \\
\text { been some limited uses } \\
\text { in clinical assessments }\end{array}$ & $\begin{array}{l}\text { Risk of cardiac } \\
\text { arrhythmias and retinal } \\
\text { damage; It can be } \\
\text { dangerous in G6PD } \\
\text { deficiency and diabetic } \\
\text { conditions }\end{array}$ \\
\hline Hydroxychloroquine & Antimalarial agent & $\begin{array}{l}\text { In vitro activity with } \\
\text { immunomodulating } \\
\text { actions }\end{array}$ & $\begin{array}{l}\text { Stopping of viral } \\
\text { enzymes and inhibiting } \\
\text { the processes of viral } \\
\text { DNA and RNA } \\
\text { polymerase, viral } \\
\text { protein glycosylation, } \\
\text { virus assembly, new } \\
\text { virus particle transport, } \\
\text { and virus release. } \\
\text { Inhibition of cell } \\
\text { receptor ACE2 }\end{array}$ & $\begin{array}{l}\text { Pre-clinical analysis for } \\
\text { the process of definitive } \\
\text { decision against } \\
\text { COVID-19. There have } \\
\text { been some limited uses } \\
\text { in clinical assessments. } \\
\text { It can be more effective } \\
\text { from chloroquine. }\end{array}$ & $\begin{array}{l}\text { Risk of cardiac } \\
\text { arrhythmias and retinal } \\
\text { damage. It can be } \\
\text { dangerous in G6PD } \\
\text { deficiency and diabetic } \\
\text { conditions. }\end{array}$ \\
\hline Lopinavir; Ritonavir & HIV protease inhibitor & $\begin{array}{l}\text { In vitro and animal } \\
\text { models }\end{array}$ & $\begin{array}{l}\text { Binding to the main } \\
\text { protease of the virus, } \\
\text { Mpro; it can be suppress } \\
\text { coronavirus activity. }\end{array}$ & $\begin{array}{l}\text { Pre-clinical and a } \\
\text { retrospective cohort } \\
\text { study has been done. }\end{array}$ & $\begin{array}{l}\text { Risk of cardiac } \\
\text { arrhythmias }\end{array}$ \\
\hline Remdesivir & Nucleoside analog & In vitro activity & $\begin{array}{l}\text { It acts as an inhibitor of } \\
\text { RNA-dependent RNA } \\
\text { polymerases (RdRps) }\end{array}$ & $\begin{array}{l}\text { Several clinical trials are } \\
\text { currently being } \\
\text { conducted }\end{array}$ & $\begin{array}{l}\text { Gastrointestinal side } \\
\text { effects }\end{array}$ \\
\hline
\end{tabular}

\subsection{Remdesivir}

A novel drug against viruses, remdesivir, is classified as a nucleotide analog (1'-cyano-substituted adenosine nucleotide analog) with a broad-spectrum antiviral effect, especially against various RNA viruses (50). As a prodrug, remdesivir is converted into its active form GS-441524 (51). GS-441524, as an analog of the adenosine nucleotide, can reduce viral RNA production by interfering with the activity of viral RNA-dependent RNA polymerase and evading proofreading by viral exoribonuclease (ExoN) $(50,51)$. Premature termination is observed following the incorporation of remdesivir into nascent viral RNA chains. This drug was first developed by Gilead Sciences and is used for the treatment of Ebola, Marburg, and COVID-19 infections (21, $27,40)$. Remdesivir can potentially treat COVID-19. Remdesivir can effectively block COVID-19 infection at low micromolar concentrations $>100 \mu(21,27,52)$.

It has been shown that this drug can inhibit SARSCoV [half-maximal inhibitory concentration $($ IC50) $=0.069$ $\mu \mathrm{M}]$ and MERS-CoV (IC50 $=0.074 \mu \mathrm{M}$ ) replication (27, 52, 53). In Vero E6 cells, an EC50 of $0.77 \mu \mathrm{M}$ was calculated for remdesivir, while the EC90 was $1.76 \mu \mathrm{M}$ in the inhibition of COVID-19 (53-55). The administration route is intravenous (IV) the efficacy dose is $200 \mathrm{mg}$ on the first day as the loading dose, and $100 \mathrm{mg}$ once a day as the maintenance dose, and the therapeutic duration is 10 days (Table 2$)(27,53-55)$.

\subsection{Darunavir}

Darunavir is an antiretroviral protease inhibitor. Darunavir is an N, N-disubstituted benzenesulfonamide harboring an unsubstituted amino group at the 4-position used in the treatment and prevention of HIV infection and Acquired Immunodeficiency Syndrome (AIDS) (56, 57). In vitro experiments indicated that viral replication is significantly inhibited by $300 \mu \mathrm{M}$ darunavir $(29,58)$. Darunavir is being studied as a possible treatment for SARS-CoV-2 due to in vitro evidence supporting its ability to combat the infection $(58,59)$. Clinical trials are underway and expected to conclude in August 2020 (58, 59).

\subsection{Other Potential Drugs}

The other candidates for treating COVID-19 include saquinavir, indinavir, shikonin, ebselen, atazanavir, carfilzomib, tipranavir, fosamprenavir, cyclosporin A, presatovir, enzaplatovir, abacavir, carmofur, bortezomib, maribavir, raltegravir, elvitegravir, montelukast, deoxyrhapontin, polydatin, chalcone, disulfiram, tideglusib, PX- 12, TDZD-8, and cinanserin (60-64). Imatinib, as an inhibitor of type II transmembrane serine protease (TMSPSS2) and BCR-ABL kinase, inhibits the fusion of virions with the endosomal membrane $(62,64)$. Furthermore, Chinese herbs including Rhizoma Polygoni Cuspidati and Radix Sophorae Tonkinensis possibly have active ingredients that may be efficient against COVID-19 (65-67). 


\subsection{Antibiotic Therapy/Azithromycin/Teicoplanin}

Antibiotic resistance may lead to more COVID-19 deaths in relation to bacterial superinfections (68). In response to this risk, antibiotic therapy is used in supportive care (69). In one experimental protocol, a combination of hydroxychloroquine (200 mg X 3 daily for a course of 10 days), in addition to Azithromycin as a broad-spectrum antibiotic (500 $\mathrm{mg}$ on the first day, followed by $250 \mathrm{mg}$ daily for five days), was used in COVID-19 infection in France $(44,70)$.

Teicoplanin is a glycopeptide antibiotic that is ordinarily utilized for the treatment of Staphylococcal infections. It was discovered to be active against SARS-CoV in vitro; therefore, it could be a candidate for being included in the list of therapeutic agents used against COVID-19. The inhibitory concentration (IC50) of this drug was $1.66 \mu \mathrm{M}$, being much lower than the concentration in human blood (8.78 $\mu \mathrm{M}$ dose of $400 \mathrm{mg}$ per day) $(71,72)$.

\subsection{Corticosteroid Therapy}

Corticosteroid therapy is an unsuitable choice to treat viral pneumonia; however, it may be advantageous if used in the early acute phase of infection $(73,74)$. Corticosteroid therapy is a risk factor in systemic use in patients suffering from refractory shock or acute respiratory distress syndrome $(73,74)$. Caution should be practiced during usage $(73,74)$. The Food and Drug Administration (FDA) is assessing the utilization of nonsteroidal anti-inflammatory drugs (NSAIDs) in patients showing COVID-19 symptoms $(75,76)$. These drugs potentially have various side effects. For example, ibuprofen has been found to increase the expression of ACE2, which may worsen the symptoms in patients inflicted with COVID-19 (75-77). Corticosteroid therapy examples include acetaminophen used for temperature control and methylprednisolone used as an appropriate drug for patients with rapid disease progression $(4,76$, $78,79)$.

\subsection{COVID-19 Convalescent Plasma}

The therapeutic approach of "convalescent-plasma therapy" includes the plasma transfusion of components, including antibodies from the people who have recovered from COVID-19 into the patients who are suffering from an infection or deemed to be at high risk $(80,81)$. Convalescent plasma has a long history. It was first attempted on a few patients in 1918 during the Spanish influenza epidemic, and it also decreased the mortality rate from $16 \%$ to about $1 \%$ among patients suffering from the Argentine hemorrhagic fever. Furthermore, the use of plasma therapy reduced the hospitalization period among patients in Hong Kong suffering from the severe acute respiratory syndrome, and this therapy has also been employed for
Ebola treatment (82-84). In convalescent-plasma therapy for COVID-19, plasma must only be collected from individuals who have recovered from COVID-19, based on the premise that plasma transfusion protocols may contain antibodies against the virus $(80,81,85)$. This method is not intended for the prevention of infection (80). The optimal ratio of $>1: 320$ of neutralizing antibody titers may be transferred. Currently, there is a clinical report from Shenzhen Third People's Hospital, China, from January 20, 2020, to March 25, 2020, where the best results have been documented, and clinical manifestations were compared with patients before and after convalescent plasma transfusion $(80,86)$.

\section{Conclusion}

Given the deteriorating conditions in the world due to COVID-19 infection, as well as the possible delays in the production of specific drugs and vaccines, examining the effects of drugs already used in the treatment of viral diseases can help manage the current situation. Although these drugs can have a variety of side effects, in many cases, these side effects can be negligible for saving the patient's life. The true effect of these drugs on COVID-19 disease can be confirmed after careful, extensive studies.

\section{Footnotes}

Authors' Contribution: Conception and constructing an idea or hypothesis for research: Mehrdad Mohammadi; manuscript design, planning, and methodology to reach the conclusion: Mehrdad Mohammadi; supervision and organizing the course of the project or the article and taking the responsibility: Mehrdad Mohammadi; data collection and/or processing, taking responsibility in the execution of experiments, patient follow-up, data management, and reporting: Mehrdad Mohammadi and Ahmad Piroozmand; analysis and/or interpretation, taking responsibility in logical interpretation, and presentation of the results: Mehrdad Mohammadi; literature review and taking responsibility in this necessary function: Tim Sandle; taking responsibility in the construction of the whole or body of the manuscript: Mehrdad Mohammadi; critical review of the article before submission for spelling, grammar, and intellectual content: Tim Sandle

Conflict of Interests: The authors declare no conflict of interest.

Funding/Support: None. 


\section{References}

1. Zhu N, Zhang D, Wang W, Li X, Yang B, Song J, et al. A Novel Coronavirus from Patients with Pneumonia in China, 2019. N Engl J Med. 2020;382(8):727-33. doi: 10.1056/NEJMoa2001017. [PubMed: 31978945]. [PubMed Central: PMC7092803].

2. Wu F, Zhao S, Yu B, Chen YM, Wang W, Song ZG, et al. A new coronavirus associated with human respiratory disease in China. $\mathrm{Na}$ ture. 2020;579(7798):265-9. doi: 10.1038/s41586-020-2008-3. [PubMed: 32015508]. [PubMed Central: PMC7094943].

3. Tang JW, Tambyah PA, Hui DSC. Emergence of a novel coronavirus causing respiratory illness from Wuhan, China. J Infect. 2020;80(3):350-71. doi: 10.1016/j.jinf.2020.01.014. [PubMed: 32001309]. [PubMed Central: PMC7127306 interests/personal relationships which may be considered as potential competing interests].

4. Wong J, Goh QY, Tan Z, Lie SA, Tay YC, Ng SY, et al. Preparing for a COVID-19 pandemic: a review of operating room outbreak response measures in a large tertiary hospital in Singapore. Can J Anaesth. 2020;67(6):732-45. doi: 10.1007/s12630-020-01620-9. [PubMed: 32162212]. [PubMed Central: PMC7090449].

5. Rothan HA, Byrareddy SN. The epidemiology and pathogenesis of coronavirus disease (COVID-19) outbreak. J Autoimmun. 2020;109:102433. doi: 10.1016/j.jaut.2020.102433. [PubMed: 32113704]. [PubMed Central: PMC7127067].

6. Corman V, Bleicker T, Brünink S, Drosten C, Zambon M. Diagnostic detection of 2019-nCoV by real-time RT-PCR. World Health Organization; 2020

7. Chen Y, Liu Q, Guo D. Emerging coronaviruses: Genome structure, replication, and pathogenesis. J Med Virol. 2020;92(4):41823. doi: 10.1002/jmv.25681. [PubMed: 31967327]. [PubMed Central: PMC7167049]

8. Lu R, Zhao X, Li J, Niu P, Yang B, Wu H, et al. Genomic characterisation and epidemiology of 2019 novel coronavirus: implications for virus origins and receptor binding. Lancet. 2020;395(10224):565-74 doi:10.1016/s0140-6736(20)30251-8.

9. Chan JF, Kok KH, Zhu Z, Chu H, To KK, Yuan S, et al. Genomic characterization of the 2019 novel human-pathogenic coronavirus isolated from a patient with atypical pneumonia after visiting Wuhan. Emerg Microbes Infect. 2020;9(1):221-36. doi: 10.1080/22221751.2020.1719902. [PubMed: 31987001]. [PubMed Central: PMC7067204].

10. Guo YR, Cao QD, Hong ZS, Tan YY, Chen SD, Jin HJ, et al. The origin, transmission and clinical therapies on coronavirus disease 2019 (COVID-19) outbreak-an update on the status.Mil Med Res.2020;7(1):11. doi: 10.1186/s40779-020-00240-0. [PubMed: 32169119]. [PubMed Central: PMC7068984].

11. Li X, Geng M, Peng Y, Meng L, Lu S. Molecular immune pathogenesis and diagnosis of COVID-19. J Pharm Anal. 2020;10(2):102-8. doi: 10.1016/j.jpha.2020.03.001. [PubMed: 32282863]. [PubMed Central: PMC7104082].

12. Hoffmann M, Kleine-Weber H, Krüger N, Müller M, Drosten C, Pöhlmann S. The novel coronavirus 2019 (2019-nCoV) uses the SARScoronavirus receptor ACE2 and the cellular protease TMPRSS2 for entry into target cells. bioRxiv. 2020. doi: 10.1101/2020.01.31.929042.

13. Walls AC, Park Y, Tortorici M, Wall A, McGuire AT, Veesler D. Structure, Function, and Antigenicity of the SARS-CoV-2 Spike Glycoprotein. Cell. 2020. doi: 10.1101/2020.02.19.956581.

14. Liu C, Yang Y, Gao Y, Shen C, Ju B, Liu C, et al. Viral Architecture of SARSCoV-2 with Post-Fusion Spike Revealed by Cryo-EM. bioRxiv. 2020. doi: 10.1101/2020.03.02.972927.

15. Li W, Moore MJ, Vasilieva N, Sui J, Wong SK, Berne MA, et al. Angiotensin-converting enzyme 2 is a functional receptor for the SARS coronavirus. Nature. 2003;426(6965):450-4. doi: 10.1038/nature02145. [PubMed: 14647384]. [PubMed Central: PMC7095016].

16. Hoffmann M, Kleine-Weber H, Schroeder S, Kruger N, Herrler T, Erichsen S, et al.SARS-CoV-2 Cell Entry Depends on ACE2 and TMPRSS2 and Is
Blocked by a Clinically Proven Protease Inhibitor. Cell.2020;181(2):271280 e8. doi: 10.1016/j.cell.2020.02.052. [PubMed: 32142651]. [PubMed Central: PMC7102627].

17. Chan JF, Yuan S, Kok KH, To KK, Chu H, Yang J, et al. A familial cluster of pneumonia associated with the 2019 novel coronavirus indicating person-to-person transmission: a study of a family cluster. Lancet 2020;395(10223):514-23. doi:10.1016/S0140-6736(20)30154-9. [PubMed 31986261]. [PubMed Central: PMC7159286].

18. Tahir Ul Qamar M, Alqahtani SM, Alamri MA, Chen LL. Structural basis of SARS-CoV-2 3CL(pro) and anti-COVID-19 drug discovery from medicinal plants. J Pharm Anal. 2020;10(4):313-9. doi: 10.1016/j.jpha.2020.03.009. [PubMed: 32296570]. [PubMed Central: PMC7156227]

19. Zumla A, Chan JF, Azhar EI, Hui DS, Yuen KY. Coronaviruses - drug discovery and therapeutic options. Nat Rev Drug Discov. 2016;15(5):32747. doi: 10.1038/nrd.2015.37. [PubMed: 26868298]. [PubMed Central: PMC7097181]

20. Zhou Y, Hou Y, Shen J, Huang Y, Martin W, Cheng F. Network-based drug repurposing for novel coronavirus 2019-nCoV/SARS-CoV-2. Cell Discov. 2020;6:14. doi: 10.1038/s41421-020-0153-3. [PubMed: 32194980] [PubMed Central: PMC7073332].

21. Belhadi D, Peiffer-Smadja N, Lescure F, Yazdanpanah Y, Mentré F, Laouénan C. A brief review of antiviral drugs evaluated in registered clinical trials for COVID-19. medRxiv. 2020. doi: 10.1101/2020.03.18.20038190.

22. Liu X, Wang X. Potential inhibitors for 2019-nCoV coronavirus $M$ protease from clinically approved medicines. bioRxiv. 2020. doi: 10.1101/2020.01.29.924100.

23. Jin YH, Cai L, Cheng ZS, Cheng H, Deng T, Fan YP, et al. A rapid advice guideline for the diagnosis and treatment of 2019 novel coronavirus (2019-nCoV) infected pneumonia (standard version). Mil Med Res. 2020;7(1):4. doi: 10.1186/s40779-020-0233-6. [PubMed: 32029004]. [PubMed Central: PMC7003341].

24. Cortegiani A, Ingoglia G, Ippolito M, Giarratano A, Einav S. A systematic review on the efficacy and safety of chloroquine for the treatment of COVID-19. JCrit Care. 2020;57:279-83. doi:10.1016/j.jcrc.2020.03.005. [PubMed: 32173110]. [PubMed Central: PMC7270792].

25. Loutfy MR, Blatt LM, Siminovitch KA, Ward S, Wolff B, Lho H, et al. Interferon alfacon-1 plus corticosteroids in severe acute respiratory syndrome: a preliminary study. JAMA. 2003;290(24):3222-8. doi: 10.1001/jama.290.24.3222. [PubMed:14693875].

26. Chen F, Chan KH, Jiang Y, Kao RY, Lu HT, Fan KW, et al. In vitro susceptibility of 10 clinical isolates of SARS coronavirus to selected antiviral compounds. J Clin Virol. 2004;31(1):69-75. doi: 10.1016/j.jcv.2004.03.003. [PubMed: 15288617]. [PubMed Central: PMC7128415].

27. Sheahan TP, Sims AC, Leist SR, Schafer A, Won J, Brown AJ, et al. Comparative therapeutic efficacy of remdesivir and combination lopinavir, ritonavir, and interferon beta against MERS-CoV. Nat Commun. 2020;11(1):222. doi: 10.1038/s41467-019-13940-6. [PubMed: 31924756]. [PubMed Central: PMC6954302].

28. Shen KL, Yang YH. Diagnosis and treatment of 2019 novel coronavirus infection in children: a pressing issue. World J Pediatr. 2020;16(3):21921. doi: 10.1007/s12519-020-00344-6. [PubMed: 32026147]. [PubMed Central: PMC7091265]

29. Lin S, Shen R, He J, Li X, Guo X. Molecular Modeling Evaluation of the Binding Effect of Ritonavir, Lopinavir and Darunavir to Severe Acute Respiratory Syndrome Coronavirus 2 Proteases. bioRxiv. 2020. doi: 10.1101/2020.01.31.929695.

30. Chu CM, Cheng VC, Hung IF, Wong MM, Chan KH, Chan KS et al. Role of lopinavir/ritonavir in the treatment of SARS: initial virological and clinical findings. Thorax. 2004;59(3):252-6. doi 10.1136/thorax.2003.012658. [PubMed: 14985565]. [PubMed Central: PMC1746980]. 
31. Pham K, Li D, Guo S, Penzak S, Dong X. Development and in vivo evaluation of child-friendly lopinavir/ritonavir pediatric granules utilizing novel in situ self-assembly nanoparticles. J Control Release. 2016;226:88-97. doi: 10.1016/j.jconrel.2016.02.001. [PubMed: 26849919].

32. Su B, Wang $Y$, Zhou R, Jiang $T$, Zhang $\mathrm{H}$, Li Z, et al. Efficacy and Tolerability of Lopinavir/Ritonavir- and Efavirenz-Based Initial Antiretroviral Therapy in HIV-1-Infected Patients in a Tertiary Care Hospital in Beijing, China. Front Pharmacol. 2019;10:1472. doi: 10.3389/fphar.2019.01472. [PubMed: 31920659]. [PubMed Central: PMC6920196].

33. Cao B, Wang Y, Wen D, Liu W, Wang J, Fan G, et al. A Trial of LopinavirRitonavir in Adults Hospitalized with Severe Covid-19. N Engl J Med. 2020;382(19):1787-99. doi: 10.1056/NEJMoa2001282. [PubMed: 32187464]. [PubMed Central: PMC7121492].

34. Yao TT, Qian JD, Zhu WY, Wang Y, Wang GQ. A systematic review of lopinavir therapy for SARS coronavirus and MERS coronavirus-A possible reference for coronavirus disease-19 treatment option. J Med Virol. 2020;92(6):556-63. doi: 10.1002/jmv.25729. [PubMed: 32104907]. [PubMed Central: PMC7217143].

35. Peiris JS, Chu CM, Cheng VC, Chan KS, Hung IF, Poon LL, et al. Clinical progression and viral load in a community outbreak of coronavirus-associated SARS pneumonia: a prospective study. Lancet. 2003;361(9371):1767-72. doi: 10.1016/s0140-6736(03)13412-5. [PubMed: 12781535]. [PubMed Central: PMC7112410].

36. Wu J, Liu J, Zhao X, Liu C, Wang W, Wang D, et al. Clinical Characteristics of Imported Cases of Coronavirus Disease 2019 (COVID19) in Jiangsu Province: A Multicenter Descriptive Study. Clin Infect Dis. 2020;71(15):706-12. doi: 10.1093/cid/ciaa199. [PubMed: 32109279]. [PubMed Central: PMC7108195].

37. Zhang C, Huang S, Zheng F, Dai Y. Controversial treatments: An updated understanding of the coronavirus disease 2019. J Med Virol. 2020. doi: 10.1002/jmv.25788. [PubMed: 32219882]. [PubMed Central: PMC7228369].

38. Elfiky AA. Anti-HCV, nucleotide inhibitors, repurposing against COVID-19. Life Sci. 2020;248:117477. doi: 10.1016/j.lfs.2020.117477. [PubMed: 32119961]. [PubMed Central: PMC7089605].

39. Fox RI. Mechanism of action of hydroxychloroquine as an antirheumatic drug. Semin Arthritis Rheum. 1993;23(2 Suppl 1):82-91. doi: 10.1016/s0049-0172(10)80012-5. [PubMed: 8278823].

40. Wang M, Cao R, Zhang L, Yang X, Liu J, Xu M, et al. Remdesivir and chloroquine effectively inhibit the recently emerged novel coronavirus (2019-nCoV) in vitro. Cell Res. 2020;30(3):269-71. doi: 10.1038/s41422-020-0282-0. [PubMed: 32020029]. [PubMed Central: PMC7054408].

41. Colson P, Rolain JM, Lagier JC, Brouqui P, Raoult D. Chloroquine and hydroxychloroquine as available weapons to fight COVID-19. Int J Antimicrob Agents. 2020;55(4):105932. doi: 10.1016/j.ijantimicag.2020.105932. [PubMed: 32145363]. [PubMed Central: PMC7135139].

42. Gao J, Tian Z, Yang X. Breakthrough: Chloroquine phosphate has shown apparent efficacy in treatment of COVID-19 associated pneumonia in clinical studies. Biosci Trends. 2020;14(1):72-3. doi: 10.5582/bst.2020.01047. [PubMed: 32074550].

43. Yao X, Ye F, Zhang M, Cui C, Huang B, Niu P, et al. In Vitro Antiviral Activity and Projection of Optimized Dosing Design of Hydroxychloroquine for the Treatment of Severe Acute Respiratory Syndrome Coronavirus 2 (SARS-CoV-2). Clin Infect Dis. 2020;71(15):7329. doi: 10.1093/cid/ciaa237. [PubMed: 32150618]. [PubMed Central: PMC7108130].

44. Gautret P, Lagier JC, Parola P, Hoang VT, Meddeb L, Mailhe M, et al. Hydroxychloroquine and azithromycin as a treatment of COVID-19: results of an open-label non-randomized clinical trial. Int J Antimicrob Agents. 2020;56(1):105949. doi: 10.1016/j.ijantimicag.2020.105949. [PubMed: 32205204]. [PubMed Central: PMC7102549].

45. Singh AK, Singh A, Shaikh A, Singh R, Misra A. Chloroquine and hy- droxychloroquine in the treatment of COVID-19 with or without diabetes: A systematic search and a narrative review with a special reference to India and other developing countries. Diabetes Metab Syndr. 2020;14(3):241-6. doi: 10.1016/j.dsx.2020.03.011. [PubMed: 32247211]. [PubMed Central: PMC7102587].

46. Blaising J, Polyak SJ, Pecheur EI. Arbidol as a broad-spectrum antiviral: an update. Antiviral Res. 2014;107:84-94. doi: 10.1016/j.antiviral.2014.04.006. [PubMed: 24769245]. [PubMed Central: PMC7113885].

47. Chen C, Zhang Y, Huang J, Yin P, Cheng Z, Wu J, et al. Favipiravir versus Arbidol for COVID-19: A Randomized Clinical Trial. medRxiv. 2020. doi: 10.1101/2020.03.17.20037432.

48. Furuta Y, Komeno T, Nakamura T. Favipiravir (T-705), a broad spectrum inhibitor of viral RNA polymerase. Proc Jpn Acad Ser B Phys Biol Sci. 2017;93(7):449-63. doi: 10.2183/pjab.93.027. [PubMed: 28769016]. [PubMed Central: PMC5713175].

49. Delang L, Abdelnabi R, Neyts J. Favipiravir as a potential countermeasure against neglected and emerging RNA viruses. Antiviral Res. 2018;153:85-94. doi: 10.1016/j.antiviral.2018.03.003. [PubMed: 29524445].

50. Agostini ML, Andres EL, Sims AC, Graham RL, Sheahan TP, Lu X, et al. Coronavirus Susceptibility to the Antiviral Remdesivir (GS-5734) Is Mediated by the Viral Polymerase and the Proofreading Exoribonuclease. mBio. 2018;9(2). doi: 10.1128/mBio.00221-18. [PubMed: 29511076]. [PubMed Central: PMC5844999].

51. Brown AJ, Won JJ, Graham RL, Dinnon K3, Sims AC, Feng JY, et al. Broad spectrum antiviral remdesivir inhibits human endemic and zoonotic deltacoronaviruses with a highly divergent RNA dependent RNA polymerase. Antiviral Res. 2019;169:104541. doi: 10.1016/j.antiviral.2019.104541. [PubMed: 31233808]. [PubMed Central: PMC6699884].

52. Ko WC, Rolain JM, Lee NY, Chen PL, Huang CT, Lee PI, et al. Arguments in favour of remdesivir for treating SARS-CoV-2 infections. Int J Antimicrob Agents. 2020;55(4):105933. doi:10.1016/j.ijantimicag.2020.105933. [PubMed: 32147516]. [PubMed Central: PMC7135364].

53. de Wit E, Feldmann F, Cronin J, Jordan R, Okumura A, Thomas T, et al. Prophylactic and therapeutic remdesivir (GS-5734) treatment in the rhesus macaque model of MERS-CoV infection. Proc Natl Acad Sci USA. 2020;117(12):6771-6. doi: 10.1073/pnas.1922083117. [PubMed: 32054787]. [PubMed Central: PMC7104368].

54. Wu C, Liu Y, Yang Y, Zhang P, Zhong W, Wang Y, et al. Analysis of therapeutic targets for SARS-CoV-2 and discovery of potential drugs by computational methods. Acta Pharm Sin B. 2020;10(5):766-88. doi: 10.1016/j.apsb.2020.02.008. [PubMed: 32292689]. [PubMed Central: PMC7102550].

55. Lai CC, Shih TP, Ko WC, Tang HJ, Hsueh PR. Severe acute respiratory syndrome coronavirus 2 (SARS-CoV-2) and coronavirus disease-2019 (COVID-19): The epidemic and the challenges. Int J Antimicrob Agents. 2020;55(3):105924. doi: 10.1016/j.ijantimicag.2020.105924. [PubMed: 32081636]. [PubMed Central: PMC7127800].

56. Back D, Sekar V, Hoetelmans RM. Darunavir: pharmacokinetics and drug interactions. Antivir Ther. 2008;13(1):1-13. [PubMed: 18389894].

57. McKeage K, Perry CM, Keam SJ. Darunavir: a review of its use in the management of HIV infection in adults. Drugs. 2009;69(4):477-503. doi: 10.2165/00003495-200969040-00007. [PubMed: 19323590].

58. Hu Z, Song C, Xu C, Jin G, Chen Y, Xu X, et al. Clinical characteristics of 24 asymptomatic infections with COVID-19 screened among close contacts in Nanjing, China. Sci China Life Sci. 2020;63(5):706-11. doi: 10.1007/s11427-020-1661-4. [PubMed: 32146694]. [PubMed Central: PMC7088568].

59. Dhama K, Sharun K, Tiwari R, Dadar M, Malik YS, Singh KP, et al. COVID-19, an emerging coronavirus infection: advances and prospects in designing and developing vaccines, immunotherapeutics, and therapeutics. Hum Vaccin Immunother. 2020;16(6):1232-8. doi: 10.1080/21645515.2020.1735227. [PubMed: 32186952]. [PubMed Central: 
PMC7103671].

60. Dong L, Hu S, Gao J. Discovering drugs to treat coronavirus disease 2019 (COVID-19). Drug Discov Ther. 2020;14(1):58-60. doi: 10.5582/ddt.2020.01012. [PubMed: 32147628].

61. Chang Y, Tung Y, Lee K, Chen T, Hsiao Y, Chang H, et al. Potential therapeutic agents for COVID-19 based on the analysis of protease and RNA polymerase docking. PrePrints. 2020. doi: 10.20944/preprints202002.0242.v1.

62. Chandel V, Raj S, Rathi B, Kumar D. In Silico Identification of Potent COVID-19 Main Protease Inhibitors from FDA Approved Antiviral Compounds and Active Phytochemicals through Molecular Docking: A Drug Repurposing Approach. PrePrints. 2020. doi: 10.20944/preprints202003.0349.v1.

63. Dayer MR. Old Drugs for Newly Emerging Viral Disease, COVID-19: Bioinformatic Prospective. arXiv. 2020.

64. Redaelli S, Piazza R, Rostagno R, Magistroni V, Perini P, Marega $\mathrm{M}$, et al. Activity of bosutinib, dasatinib, and nilotinib against 18 imatinib-resistant BCR/ABL mutants. J Clin Oncol. 2009;27(3):469-71. doi: 10.1200/JCO.2008.19.8853. [PubMed: 19075254].

65. Wu Z, McGoogan JM. Characteristics of and Important Lessons From the Coronavirus Disease 2019 (COVID-19) Outbreak in China: Summary of a Report of 72314 Cases From the Chinese Center for Disease Control and Prevention. JAMA. 2020;323(13):1239-42. doi: 10.1001/jama.2020.2648. [PubMed: 32091533].

66. Ang L, Lee HW, Choi JY, Zhang J, Soo Lee M. Herbal medicine and pattern identification for treating COVID-19: a rapid review of guidelines.Integr Med Res.2020;9(2):100407. doi:10.1016/j.imr.2020.100407. [PubMed: 32289016]. [PubMed Central: PMC7104236].

67. Luo H, Tang QL, Shang YX, Liang SB, Yang M, Robinson N, et al. Can Chinese Medicine Be Used for Prevention of Corona Virus Disease 2019 (COVID-19)? A Review of Historical Classics, Research Evidence and Current Prevention Programs. Chin J Integr Med. 2020;26(4):243-50. doi: 10.1007/s11655-020-3192-6. [PubMed: 32065348]. [PubMed Central: PMC7088641].

68. Amsden GW. Anti-inflammatory effects of macrolides-an underappreciated benefit in the treatment of community-acquired respiratory tract infections and chronic inflammatory pulmonary conditions? J Antimicrob Chemother. 2005;55(1):10-21. doi: 10.1093/jac/dkh519. [PubMed: 15590715].

69. Nadeem Ahmed M, Muyot MM, Begum S, Smith P, Little C, Windemuller FJ. Antibiotic prescription pattern for viral respiratory illness in emergency room and ambulatory care settings. Clin Pediatr (Phila). 2010;49(6):542-7. doi: 10.1177/0009922809357786. [PubMed: 20075029].

70. Wang D, Hu B, Hu C, Zhu F, Liu X, Zhang J, et al. Clinical Characteristics of 138 Hospitalized Patients With 2019 Novel CoronavirusInfected Pneumonia in Wuhan, China. JAMA. 2020;323(11):1061-9. doi: 10.1001/jama.2020.1585. [PubMed: 32031570]. [PubMed Central: PMC7042881].

71. Baron SA, Devaux C, Colson P, Raoult D, Rolain JM. Teicoplanin: an alternative drug for the treatment of COVID-19? Int J Antimicrob Agents. 2020;55(4):105944. doi: 10.1016/j.ijantimicag.2020.105944. [PubMed: 32179150]. [PubMed Central: PMC7102624].

72. Zhang J, Ma X, Yu F, Liu J, Zou F, Pan T, et al. Teicoplanin potently blocks the cell entry of 2019-nCoV. bioRxiv. 2020. doi:
10.1101/2020.02.05.935387.

73. Cao B, Gao H, Zhou B, Deng X, Hu C, Deng C, et al. Adjuvant Corticosteroid Treatment in Adults With Influenza $A$ (H7N9) Viral Pneumonia. Crit Care Med. 2016;44(6):e318-28. doi: 10.1097/CCM.0000000000001616. [PubMed: 26934144].

74. Diaz E, Martin-Loeches I, Canadell L, Vidaur L, Suarez D, Socias L, et al. Corticosteroid therapy in patients with primary viral pneumonia due to pandemic (H1N1) 2009 influenza. J Infect. 2012;64(3):311-8. doi: 10.1016/j.jinf.2011.12.010. [PubMed: 22240033].

75. Wang Y, Jiang W, He Q, Wang C, Wang B, Zhou P, et al. Early, lowdose and short-term application of corticosteroid treatment in patients with severe COVID-19 pneumonia: single-center experience from Wuhan, China. medRxiv. 2020. doi: 10.1101/2020.03.06.20032342.

76. Shang L, Zhao J, Hu Y, Du R, Cao B. On the use of corticosteroids for 2019-nCoV pneumonia. Lancet. 2020;395(10225):683-4. doi: 10.1016/S0140-6736(20)30361-5. [PubMed: 32122468]. [PubMed Central: PMC7159292].

77. Chen C, Qi F, Shi K, Li Y, Li J, Chen Y, et al. Thalidomide combined with low-dose short-term glucocorticoid in the treatment of COVID19 pneumonia. Clin Trans Med. 2020.

78. Young BE, Ong SWX, Kalimuddin S, Low JG, Tan SY, Loh J, et al. Epidemiologic Features and Clinical Course of Patients Infected With SARS-CoV-2 in Singapore. JAMA. 2020;323(15):1488-94. doi: 10.1001/jama.2020.3204. [PubMed: 32125362]. [PubMed Central: PMC7054855].

79. Yang X, Yu Y, Xu J, Shu H, Xia J, Liu H, et al. Clinical course and outcomes of critically ill patients with SARS-CoV-2 pneumonia in Wuhan, China: a single-centered, retrospective, observational study. Lancet Resp Med. 2020;8(5):475-81. doi: 10.1016/s2213-2600(20)30079-5.

80. Chen L, Xiong J, Bao L, Shi Y. Convalescent plasma as a potential therapy for COVID-19. Lancet Infect Dis. 2020;20(4):398-400. doi: 10.1016/s1473-3099(20)30141-9.

81. Tanne JH. Covid-19: FDA approves use of convalescent plasma to treat critically ill patients. BMJ. 2020;368:m1256. doi: 10.1136/bmj.m1256. [PubMed: 32217555].

82. Petrosillo N, Nicastri E, Lanini S, Capobianchi MR, Di Caro A, Antonini $\mathrm{M}$, et al. Ebola virus disease complicated with viral interstitial pneumonia: a case report. BMC Infect Dis. 2015;15:432. doi: 10.1186/s12879015-1169-4. [PubMed: 26471197]. [PubMed Central: PMC4608352].

83. Zhou B, Zhong N, Guan Y. Treatment with convalescent plasma for influenza A (H5N1) infection. N Engl J Med. 2007;357(14):1450-1. doi: 10.1056/NEJMc070359. [PubMed: 17914053].

84. Arabi Y, Balkhy H, Hajeer AH, Bouchama A, Hayden FG, Al-Omari A, et al. Feasibility, safety, clinical, and laboratory effects of convalescent plasma therapy for patients with Middle East respiratory syndrome coronavirus infection: a study protocol. Springerplus. 2015;4:709. doi: 10.1186/s40064-015-1490-9. [PubMed: 26618098]. [PubMed Central: PMC4653124]

85. Shen C, Wang Z, Zhao F, Yang Y, Li J, Yuan J, et al. Treatment of 5 Critically Ill Patients With COVID-19 With Convalescent Plasma. JAMA. 2020;323(16):1582-9. doi: 10.1001/jama.2020.4783. [PubMed: 32219428]. [PubMed Central: PMC7101507].

86. Huang C, Wang Y, Li X, Ren L, Zhao J, Hu Y, et al. Clinical features of patients infected with 2019 novel coronavirus in Wuhan, China. Lancet. 2020;395(10223):497-506. doi: 10.1016/s0140-6736(20)30183-5. 


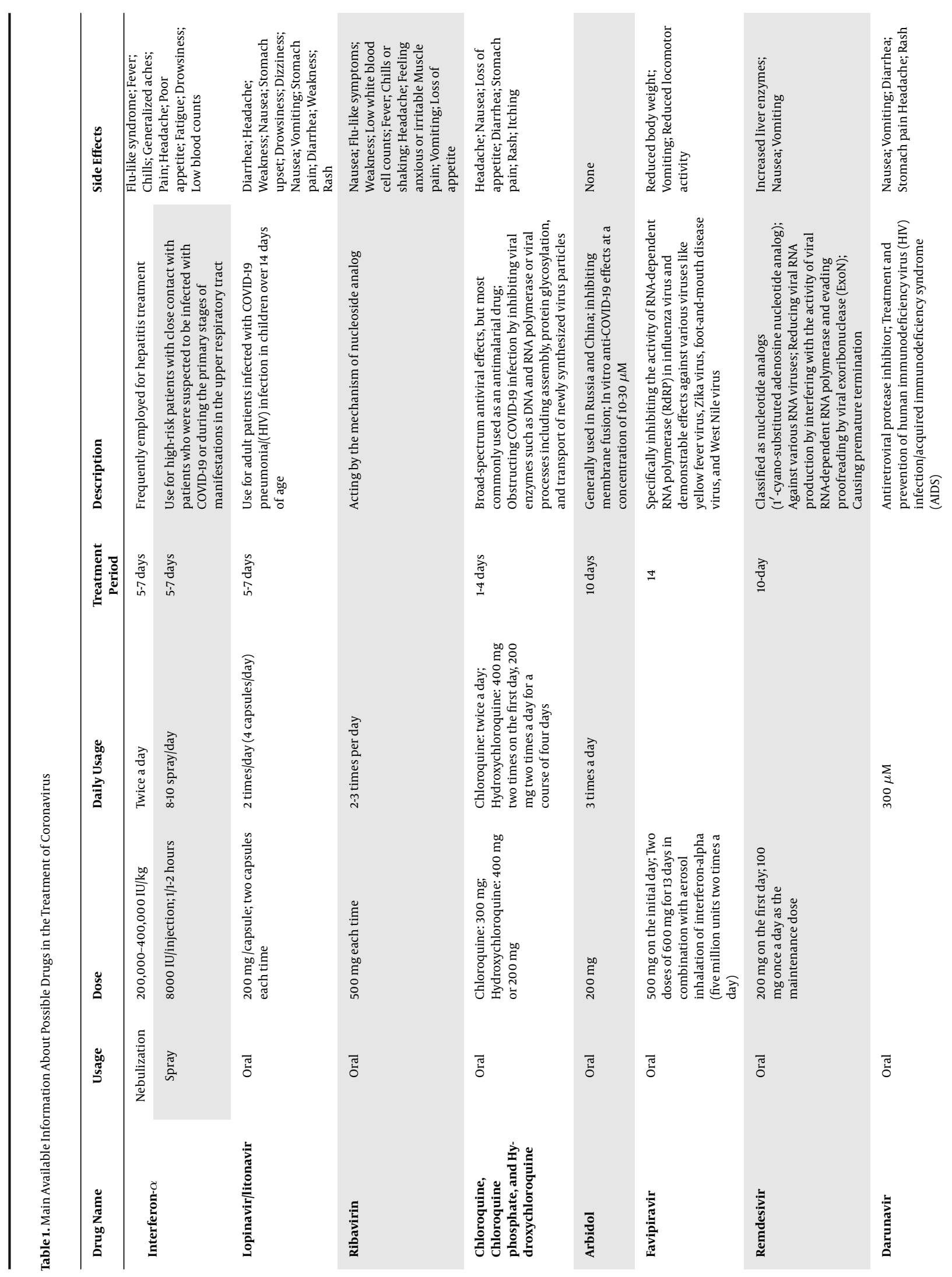




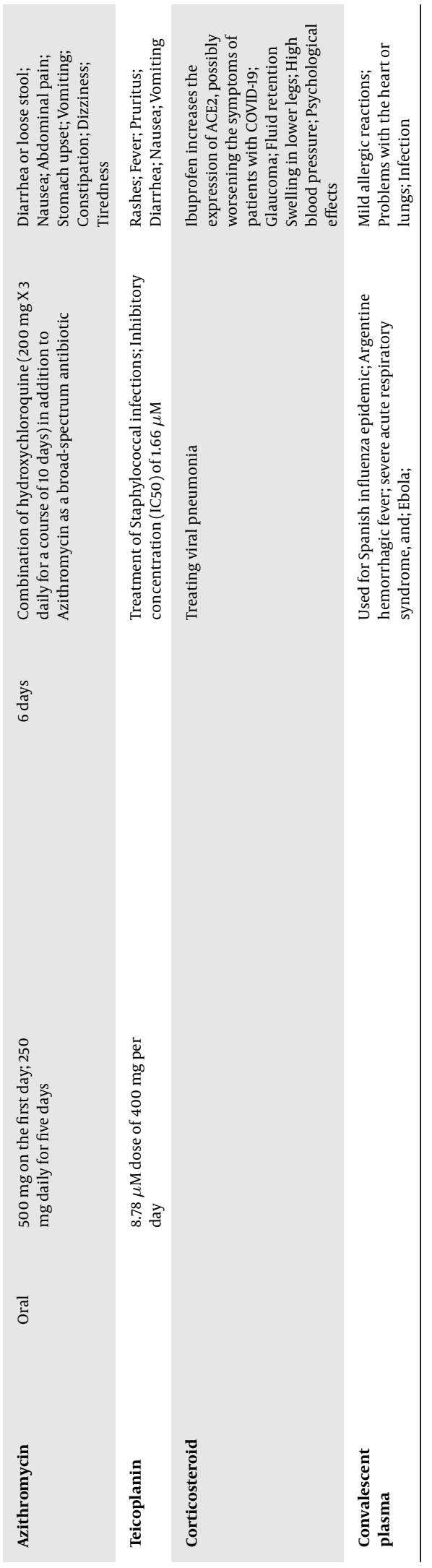

